\title{
Systemic Capillary Leak Syndrome
}

\author{
Shotetsu Kawabe, Takako Saeki, Hajime Yamazaki, Masaaki NAGaI*, Ryuji Aoyagi** and Shoji MiYamura
}

\begin{abstract}
A 40-year-old woman was referred to our hospital with severe hypovolemic shock and anasarca. The laboratory findings showed marked hemoconcentration and a decrease in total serum protein with the presence of monoclonal IgG$\lambda$. She had had a similar episode of generalized edema 2 years previously. We diagnosed the patient as having typical systemic capillary leak syndrome (SCLS) and she improved gradually after infusion of albumin-containing fluid. SCLS is a very rare condition caused by unexplained episodic capillary hyperpermeability. Its treatment has remained largely supportive and the prognosis is generally poor. Awareness of SCLS is necessary for improvement of the outcome.
\end{abstract}

(Internal Medicine 41: 211-215, 2002)

Key words: capillary hyperpermeability, hypovolemic shock, prognosis

\section{Introduction}

Systemic capillary leak syndrome (SCLS) is a rare condition characterized by unexplained episodic capillary hyperpermeability. This phenomenon produces a shift of fluid and protein from the intravascular to the interstitial space, with subsequent hypovolemia, hemoconcentration and hypoproteinemia. The pathogenesis of this disorder has not been elucidated and its clinical outcome is generally poor. We describe here a typical case of SCLS that was manageable by prompt treatment, and review the literature.

\section{Case Report}

In February 1998, a 38-year-old Japanese woman was admitted to Ojiya Hospital with generalized edema and oliguria after a flu-like illness. Laboratory data showed a marked increase in hematocrit (55.2\%), and a decrease in total serum protein $(4.9 \mathrm{~g} / \mathrm{dl})$ without proteinuria. She was treated with in- travenous infusion of fluids, including albumin and a diuretic drug, and the edema and laboratory abnormalities improved in a few days. Thereafter, however, she developed mild bilateral leg edema recurrently in the premenstrual period or during the menstruation. She had a history of iron deficiency anemia since the age of 24 years, but the condition had not been treated. In 1991 she was diagnosed as having bilateral thyroid tumors. She received vaccine therapy over several months, but the details of the treatment were not available.

On February 24, 2000, she was admitted to Ojiya General Hospital again because of shock and anasarca after a flu-like illness of 3 days' duration. The laboratory findings also showed marked hemoconcentration and a decrease in total protein. She was treated with intravenous fluids, albumin and dopamine immediately, but hypotension and oliguria persisted and she was transferred to our hospital on February 25. On arrival, she was fully conscious. Her body weight was $60 \mathrm{~kg}, 2 \mathrm{~kg}$ more than usual. The systolic blood pressure was $80 \mathrm{mmHg}$, and the body temperature was $36.8^{\circ} \mathrm{C}$. Lymphadenopathy was not evident. A large goiter was recognized in the thyroid gland. A chest and abdominal examination showed no abnormal findings. Her extremities were cold, pale and markedly edematous.

The results of laboratory tests on admission are summarized in Table 1. Blood cell counts revealed an increase in both hematocrit (49.9\%) and hemoglobin (16.8 g/dl). White blood cell count had increased to $21,800 / \mu 1$, with a normal fraction. Although a marked decrease in total serum protein was observed $(4.4 \mathrm{~g} / \mathrm{dl})$, urinalysis showed no proteinuria. Blood urea nitrogen and creatinine had increased to $50.7 \mathrm{mg} / \mathrm{dl}$ and $1.25 \mathrm{mg} / \mathrm{dl}$, respectively. Serum levels of IgG, C3 and C4 had decreased. $\operatorname{IgA}$ and IgM levels were normal. Thyroid function test was normal. Monoclonal immunoglobulin G- $\lambda$ was detected in the patient's serum by immunoelectrophoresis, but Bence Jones protein was negative. Bone marrow aspiration was not conducted, at the patient's request. A chest X-ray film revealed no pleural effusion, pulmonary congestion or cardiomegaly. Ultrasonographic examination of the abdomen revealed no ascites.

On the day of admission, intravenous administration of over 4.5 liters of fluid with $5 \%$ albumin was started immediately, together with dopamine $(8 \mu \mathrm{g} / \mathrm{kg} / \mathrm{min})$ and dobutamine $(5 \mu \mathrm{g} /$

From the Department of Internal Medicine, Nagaoka Red Cross Hospital, Nagaoka, *Ojiya General Hospital, Ojiya and **Tachikawa General Hospital, Nagaoka

Received for publication September 28, 2001; Accepted for publication November 19, 2001

Present address and Reprint requests should be addressed to Dr. Shotetsu Kawabe, the Second Department of Internal Medicine, Niigata University, School of Medicine, 1-757 Asahimachi-dori 1, Niigata 951-8510 
Table 1. Laboratory Data on Admission to Our Hospital

\begin{tabular}{|c|c|c|c|c|c|}
\hline \multicolumn{6}{|l|}{ Peripheral blood } \\
\hline White blood cell count & $21,800 / \mu \mathrm{l}$ & $\mathrm{Ca}$ & $9.1 \mathrm{mg} / \mathrm{dl}$ & $\mathrm{CH}_{50}$ & $37.7 \mathrm{U} / \mathrm{ml}$ \\
\hline (Neutrophil & $71.8 \%)$ & $\mathrm{P}$ & $5.8 \mathrm{mg} / \mathrm{dl}$ & Complement $\mathrm{C} 3$ & $43 \mathrm{mg} / \mathrm{dl}$ \\
\hline (Eosinophil & $0.8 \%)$ & Asparate aminotransferas & e $12 \mathrm{IU} / \mathrm{l}$ & Complement $\mathrm{C} 4$ & $11 \mathrm{mg} / \mathrm{dl}$ \\
\hline Red blood cell count & $674 \times 10^{4} / \mu 1$ & Alanine aminotransferase & $10 \mathrm{IU} / l$ & Endocrinology & \\
\hline Hemoglobin & $16.8 \mathrm{~g} / \mathrm{dl}$ & Lactate dehydrogenase & $98 \mathrm{IU} / \mathrm{l}$ & Serum Free T3 & $1.78 \mathrm{pg} / \mathrm{ml}$ \\
\hline Hematocrit & $49.9 \%$ & Alkaline phosphatase & $90 \mathrm{IU} / l$ & Serum Free T4 & $1.13 \mathrm{ng} / \mathrm{ml}$ \\
\hline MCV & $74.0 \mathrm{fl}$ & Creatine phosphokinase & $96 \mathrm{IU} / l$ & Serum TSH & $0.91 \mu \mathrm{U} / \mathrm{ml}$ \\
\hline Platelet & $33.5 \times 10^{4} / \mu \mathrm{l}$ & Glucose & $201 \mathrm{mg} / \mathrm{dl}$ & Urinalysis & \\
\hline ESR & $18 \mathrm{~mm} / \mathrm{h}$ & Serology & & Sugar & $(-)$ \\
\hline Biochemistry & & $\mathrm{C}$-reactive protein & $0.6 \mathrm{mg} / \mathrm{dl}$ & Protein & $(-)$ \\
\hline Total protein & $4.4 \mathrm{~g} / \mathrm{dl}$ & Immunoglobulin G & $497 \mathrm{mg} / \mathrm{dl}$ & Occult blood & $(-)$ \\
\hline Albumin & $3.0 \mathrm{~g} / \mathrm{dl}$ & Immunoglobulin A & $115 \mathrm{mg} / \mathrm{dl}$ & & \\
\hline Blood urea nitrogen & $50.7 \mathrm{mg} / \mathrm{dl}$ & Immunoglobulin M & $72 \mathrm{mg} / \mathrm{dl}$ & & \\
\hline Creatinine & $1.25 \mathrm{mg} / \mathrm{dl}$ & Immunoglobulin E & $30.3 \mathrm{U} / \mathrm{ml}$ & & \\
\hline $\mathrm{Na}$ & $126 \mathrm{mEq} / \mathrm{l}$ & Antinuclear antibody & negative & & \\
\hline $\mathrm{K}$ & $4.1 \mathrm{mEq} / \mathrm{l}$ & Immunoelectrophoresis & IgG- $\lambda$ & & \\
\hline $\mathrm{Cl}$ & $97 \mathrm{mEq} / \mathrm{l}$ & & & & \\
\hline
\end{tabular}

MCV: mean corpuscular volume, ESR: erythrocyte sedimentation rate, $\mathrm{CH}_{50}$ : complement hemolysis 50 , T3: triiodothyronine, $\mathrm{T} 4$ : thyroxine, TSH: thyroid stimulating hormone.

$\mathrm{kg} / \mathrm{min}$ ). The patient's systolic blood pressure returned to normal within 12 hours. Urine volume increased and the anasarca improved gradually without diuretics. The dosages of intravenous fluids and cardioactive agents were tapered and the infusion was stopped on March 1. Ten days later, her weight had decreased to $54.7 \mathrm{~kg}$ and no edema was present. The hemoglobin level was $9.0 \mathrm{~g} / \mathrm{dl}$ and total serum protein had increased to $6.9 \mathrm{~g} / \mathrm{dl}$ (albumin $4.6 \mathrm{~g} / \mathrm{dl}$ ). The serum levels of immunoglobulin and components of complement returned to normal.

We diagnosed the patient as having SCLS because of the decrease in serum protein and the increase in the hematocrit during the acute episodes of anasarca and hypotension and monoclonal gammmopathy. To prevent the disease flaring, we began administration of theophylline ( $400 \mathrm{mg}$ twice daily) in March 2000. She has continued this medication without any episode of anasarca or hypotension up to February 2001, although mild edema has developed occasionally. The patient's anemia improved with iron replacement therapy. Cervical CT scan and aspiration biopsy of the bilateral thyroid tumors (left, $5 \mathrm{~cm}$ diameter, and right, $2 \mathrm{~cm}$ diameter) revealed adenomas, which were followed up carefully.

\section{Discussion}

Idiopathic SCLS was first described by Clarkson et al (1) in 1960. Since then, 57 cases have been described in the literature, with only three cases in Japan (including the present case) to our knowledge. It is a rare condition characterized by unexplained episodic capillary permeability due to a shift of fluid and protein from the intravascular to the interstitial space. This results in recurrent episodes of generalized edema and hypovolemic shock, with hemoconcentration and hypoproteinemia.
It is well documented that most of the reported cases have been associated with monoclonal gammopathy. No patients exhibited any evidence of amyloidosis or endocrine disease during their remissions. The present patient had suffered recurrent attacks of edema and presented suddenly with shock and anasarca associated with marked elevation of hematocrit, hypoproteinemia and monoclonal gammopathy. These are typical features of SCLS.

The reported cases of SCLS in the literature (from 1960 to 2000) are summarized in Table 2 . The condition primarily affects healthy young and middle-aged adults (age range: 9 to 67, mean age \pm SD: $46.1 \pm 13.3$ ) with equal distribution between the sexes (male: 28, female: 27, unknown: 1). Forty-seven patients $(82 \%)$ had a monoclonal immunoglobulin, predominantly $\operatorname{IgG\kappa }$, in their serum. No case had a relevant familial history. Although the precise mechanism of SCLS has not been elucidated, Amoura et al (2) suggested that viral infection might trigger the attacks because many of the patients had experienced preceding episodes of flu-like illness. The present case supports this; our patient had attacks after a flu-like illness. Menstruation has been incriminated as a trigger of acute episodes (1), again as seen in our patient. As described above, most patients with SCLS have a monoclonal immunoglobulin in their serum. These findings suggest that paraproteins might have a role in inducing capillary hyperpermeability, but this has not been demonstrated. On the other hand, conditions closely resembling SCLS have been observed in patients receiving recombinant interleukin 2 (IL-2) therapy $(3,4)$. This observation has provided a clue to the mechanism of SCLS and it has been hypothesized that cytokines, most notably IL2 , cause endothelial damage and capillary hyperpermeability $(5,6)$. The presence of IL-2-receptor positive cells and perivas- 
Table 2. Reported Cases of SCLS

\begin{tabular}{|c|c|c|c|c|c|c|}
\hline Case & $\begin{array}{c}\text { Year } \\
\text { (Reference) }\end{array}$ & Age & Sex & $\begin{array}{l}\text { Monoclonal } \\
\text { compornent }\end{array}$ & Therapy & Out come \\
\hline 1 & $1960(1)$ & 32 & $\mathrm{~F}$ & $\mathrm{IgG}$ & steroid & died after 3 years \\
\hline 2 & 1963 (14) & 45 & $\mathrm{M}$ & $\mathrm{IgG}$ & $?$ & $?$ \\
\hline 3 & $1967(15)$ & $\begin{array}{l}4 J \\
52\end{array}$ & $\mathrm{M}$ & normal & fluid therapy & died after 4 years \\
\hline 4 & 1969 (16) & 45 & $\mathrm{~F}$ & IgGK & $?$ & died after 3 years \\
\hline 5 & $1973(17)$ & 47 & $\mathbf{M}$ & + & $?$ & died after 8 years \\
\hline 6 & $1975(18)$ & 40 & M & $\operatorname{IgG\kappa }$ & $?$ & alive for 6 years \\
\hline 7 & 1977 (19) & 40 & $\mathbf{M}$ & $\operatorname{IgG} \lambda$ & fluid therapy & died after 3 years \\
\hline 8 & $1978(20)$ & 37 & $\mathrm{~F}$ & $\operatorname{IgG\kappa }$ & fluid therapy & ? \\
\hline 9 & $1979(21)$ & 43 & $\mathbf{M}$ & $\operatorname{IgG} \lambda$ & terbutaline & alive for 4 years \\
\hline 10 & $1981(22)$ & $\begin{array}{l}45 \\
69\end{array}$ & $\mathrm{M}$ & $\operatorname{IgG\kappa }$ & steroid & alive for 0.5 years \\
\hline 11 & $1981(23)$ & $?$ & $?$ & $\mathrm{IgG \kappa}$ & $?$ & $?$ \\
\hline 12 & $1982(24)$ & 22 & $\mathrm{~F}$ & $?$ & $?$ & $?$ \\
\hline 13 & $1983(25)$ & 21 & $\mathrm{~F}$ & $?$ & fluid therapy & died after 1 year \\
\hline 14 & $1985(26)$ & 63 & $\mathrm{~F}$ & $\mathrm{IgG}$ & fluid therapy & $?$ \\
\hline 15 & $1986(27)$ & 45 & $\mathbf{M}$ & IgG & fluid therapy & $?$ \\
\hline 16 & $1986(28)$ & 37 & $\mathrm{~F}$ & $\operatorname{IgG\kappa }$ & fluid therapy & alive for 10 years \\
\hline 17 & $1987(29)$ & 37 & $\mathrm{M}$ & $\operatorname{IgG\kappa }$ & fluid therapy & alive for 6 years \\
\hline 18 & $1987(29)$ & 44 & $\mathrm{~F}$ & $\operatorname{IgG\kappa }$ & fluid therapy & alive for 5 years \\
\hline 19 & $1987(30)$ & 33 & $\mathbf{M}$ & IgGK & $\mathrm{T}+\mathrm{A}, \mathrm{IVIg}$ & alive for 6 years \\
\hline 20 & $1988(31)$ & 49 & $\mathbf{M}$ & $\operatorname{IgG\kappa }$ & $?$ & alive for 5 years \\
\hline 21 & $1988(32)$ & 39 & $\mathrm{~F}$ & $\mathrm{IgG \kappa}$ & PEX, MP & alive for 4 years \\
\hline 22 & $1988(33)$ & 39 & M & $\operatorname{IgG\kappa }, \lambda$ & terbutaline & died after 5 years \\
\hline 23 & $1988(34)$ & 55 & $\mathrm{~F}$ & ? & fluid therapy & ? \\
\hline 24 & $1989(35)$ & 46 & $\mathrm{M}$ & $\mathrm{IgG \kappa}$ & fluid therapy & died after 1.5 years \\
\hline 25 & $1990(7)$ & 52 & $\mathrm{~F}$ & $\mathrm{IgG \kappa}$ & fluid therapy & alive for 3 years \\
\hline 26 & $1990(36)$ & $\begin{array}{l}52 \\
37\end{array}$ & $\mathrm{M}$ & normal & fluid therapy & ? \\
\hline 27 & $1990(36)$ & 44 & $\mathrm{~F}$ & $\operatorname{IgG} \lambda$ & fluid therapy & $?$ \\
\hline 28 & $1992(37)$ & $\begin{array}{l}44 \\
65\end{array}$ & $\mathrm{M}$ & $\operatorname{Ig} A \lambda$ & $\mathrm{T}+\mathrm{A}$ & alive for 10 years \\
\hline 29 & $1992(37)$ & 56 & $\mathbf{M}$ & IgGK & $\mathrm{T}+\mathrm{A}$ & alive for 5 years \\
\hline 30 & $1992(37)$ & 58 & $\mathrm{~F}$ & $\mathrm{IgG \kappa}$ & $\mathrm{T}+\mathrm{A}$ & alive for 3 years \\
\hline 31 & $1993(38)$ & 36 & M & $\mathrm{IgG \kappa}$ & steroid & alive for 6 years \\
\hline 32 & $1994(4)$ & 19 & $\mathbf{M}$ & normal & antibiotics & ? \\
\hline 33 & $1995(39)$ & 46 & $\mathrm{M}$ & hypoglobulin & $\mathrm{Ca}$ antagonist & $?$ \\
\hline 34 & $1995(9)$ & 34 & $\mathrm{~F}$ & IgGK & steroid & died after 3 years \\
\hline 35 & $1995(40)$ & $\begin{array}{c}34 \\
9\end{array}$ & $\mathrm{~F}$ & normal & fluid therapy & ? \\
\hline 36 & $1995(41)$ & 56 & $\mathrm{~F}$ & $\mathrm{IgG \kappa}$ & $\mathrm{T}+\mathrm{A}$, IVIg, steroid & alive for 3 years \\
\hline 37 & 1995 (13) & 67 & $\mathrm{~F}$ & $\mathrm{IgG \kappa}$ & $\mathrm{T}+\mathrm{A}$ & alive for 1 years \\
\hline 38 & $1997(2)$ & 49 & $\mathrm{~F}$ & $\mathrm{IgG \kappa}$ & $\mathrm{T}+\mathrm{A}$ & alive for 6 years \\
\hline 39 & $1997(2)$ & 53 & $\mathrm{M}$ & $\operatorname{IgG\kappa }$ & $\mathrm{T}+\mathrm{A}$ & alive for 2 years \\
\hline 40 & $1997(2)$ & 35 & $\mathrm{M}$ & IgGK & $\begin{array}{l}\mathrm{T}+\mathrm{A} \text {, steroid, cyclosporine } \\
\text { indomethacin, diuretics }\end{array}$ & alive for 7 years \\
\hline 41 & $1997(2)$ & 61 & $\mathbf{M}$ & $\operatorname{IgG\kappa }$ & $\mathrm{T}+\mathrm{A}$ & alive for 4 years \\
\hline 42 & $1997(2)$ & 53 & M & $\operatorname{IgG\kappa }$ & steroid & $?$ \\
\hline 43 & $1997(2)$ & 44 & M & IgGK & $\mathrm{T}+\mathrm{A}$, cyclosporine & alive for 6 years \\
\hline 44 & $1997(2)$ & 63 & $\mathrm{~F}$ & IgGK & $\mathrm{T}+\mathrm{A}$ & alive for 4 years \\
\hline 45 & $1997(2)$ & 64 & $\mathbf{M}$ & $\operatorname{IgG\kappa }$ & $\mathrm{T}+\mathrm{A}, \mathrm{PEX}, \mathrm{MP}$ & died after 4 years \\
\hline 46 & $1997(2)$ & 53 & $\mathrm{~F}$ & $\mathrm{IgG \kappa}$ & Gingo biloba & died after 10 years \\
\hline 47 & $1997(2)$ & 49 & $\mathrm{~F}$ & $\operatorname{IgG} \lambda$ & MP & alive for 6 years \\
\hline 48 & $1998(42)$ & 34 & $\mathbf{M}$ & IgGK & $?$ & $?$ \\
\hline 49 & $1998(43)$ & 30 & $\mathrm{~F}$ & $\operatorname{IgG\kappa }, \lambda$ & steroid & alive for 2 years \\
\hline 50 & 1999 (12) & 28 & $\mathbf{M}$ & $\mathrm{IgGK}$ & $\mathrm{T}+\mathrm{A}$ & died after 2 years \\
\hline 51 & $1999(12)$ & $\begin{array}{l}20 \\
51\end{array}$ & $\mathrm{~F}$ & $\mathrm{IgG \kappa}$ & $\mathrm{T}+\mathrm{A}$ & alive for 11 years \\
\hline 52 & 1999 (12) & 39 & $\mathrm{~F}$ & $\operatorname{IgG} \lambda$ & $\mathrm{T}+\mathrm{A}$ & alive for 10 years \\
\hline 53 & 1999 (12) & 47 & $\mathrm{M}$ & normal & $\mathrm{T}+\mathrm{A}$ & alive for 6 years \\
\hline 54 & 1999 (12) & 66 & $\mathrm{~F}$ & normal & $\mathrm{T}+\mathrm{A}$ & alive for 4 years \\
\hline 55 & $2000(44)$ & 64 & $\mathrm{~F}$ & IgGK & $\begin{array}{c}\text { theophylline, steroid } \\
\text { diuretics }\end{array}$ & alive for 7 years \\
\hline 56 & present case & 39 & $\mathrm{~F}$ & $\operatorname{IgG} \lambda$ & theophylline & alive for 3 years \\
\hline
\end{tabular}

$\mathrm{T}+\mathrm{A}$ : terbutaline+aminophylline or theophylline, IVIg: intravenous immunoglobulin, PEX: plasma exchange, MP: melphalan+prednisone. 
cular infiltrates of CD8-positive lymphocytes surrounding damaged endothelial cells during attacks in one patient have also been reported (7). Our patient had received vaccine therapy for the thyroid tumors 7 years before the attacks. It is possible that such therapy might be associated with the development of SCLS. In most cases of IL-2-induced capillary leak syndrome, however, attacks developed during the IL-2 therapy (8), and therefore the etiology in our case remains unknown.

Most cases of SCLS have a history of shock state during the acute phase due to an increase in capillary permeability, and hypovolemic shock was quite severe in our patient. When the condition has been identified, immediate and adequate replacement therapy is necessary. Intravenous fluid therapy, including albumin, should be started for the hypovolemic shock. This is essential to maintain tissue perfusion and to protect organs from the effect of the shock. In the recovery phase, however, the fluids return to the intravascular space and there is a risk of pulmonary congestion (9). Various agents have been tried for treating this problem, but their efficacy remains controversial. Steroids and diuretics have given variable results. Loop diuretics might be useful for the normalization of intravascular fluid overload.

In addition to the treatment for the acute phase, several prophylactic therapies have been tried. Recurrence is a notable feature of SCLS, so prevention of this is important. Terbutaline and theophylline therapy have been reported to be apparently effective against of SCLS recurrence. Beta-2 stimulators (terbutaline or salbutamol) can inhibit macromolecular leakage during the normalization response (10). Theophylline has immunomodulatory and anti-inflammatory activities that are useful in antagonizing cytokine-mediated endothelial damage and capillary hyperpermeability (11). Tahirkheli and Greipp (12) followed eight patients with SCLS on a regimen of terbutaline and theophylline for a median period of 9 years and demonstrated prophylactic efficacy. But some reports have denied a prophylactic effect, and the efficacy of the regimen remains unclear. Our patient has continued theophylline therapy for one year without any further episode of anasarca and hypotension, but mild edema has developed occasionally. Because SCLS is a rare disease, it is very difficult to judge the efficacy of such a regimen. Other prophylactic treatments (prednisone, Gingko biloba, plasmapheresis, intravenous immunoglobulins, cyclosporine, etc.) have been tried, but their efficacy is also unclear.

Despite aggressive resuscitation and prophylactic treatments, this syndrome is often fatal. At least $12 / 56$ patients (21.4\%) died of the disease during follow-up. The causes of death were mainly shock and pulmonary congestion (8). In three patients, SCLS evolved into multiple myeloma, of which two of three patients died $(2,13)$.

In conclusion, awareness of SCLS is most important for improving the outcome because early diagnosis and immediate fluid replacement therapy are essential. Educating patients to visit the hospital as soon as generalized edema develops, especially following any flu-like illness, is also important.

\section{References}

1) Clarkson B, Thompson D, Horwith M, et al. Cyclical edema and shock due to increased capillary permeability. Am J Med 29: 193-216, 1960.

2) Amoura $Z$, Papo T, Ninet J, et al. Systemic capillary leak syndrome: report on 13 patients with special focus on course and treatment. Am J Med 103: 514-519, 1997.

3) Rosenstein M, Ettinghausen SE, Rosenberg SA. Extravasation of intravascular fluid mediated by the systemic administration of recombinant interleukin-2. J Immunol 137: 1735-1742, 1986.

4) Funke I, Prummer O, Schrezenmeier $\mathrm{H}$, et al. Capillary leak syndrome associated with elevated IL-2 serum levels after allogeneic bone marrow transplantation. Ann Hematol 68: 49-52, 1994.

5) Baluna R, Rizo J, Gordon BE, et al. Evidence for a structural motif in toxins and interleukin-2 that may be responsible for binding to endothelial cells and initiating vascular leak syndrome. Proc Natl Acad Sci USA 96: 3957-3962, 1999.

6) Lentsch AB, Miller FN, Edwards MJ. Mechanisms of leukocyte-mediated tissue injury induced by interleukin-2. Cancer Immunol Immunother 47: 243-248, 1999.

7) Cicardi M, Berti E, Capto V, et al. Idiopathic capillary leak syndrome: evidence of CD8-positive lymphocytes surrounding damaged endothelial cells. J Allergy Clin Immunol 99: 417-419, 1997.

8) Lissoni P, Barni S, Cattaneo G. Activation of the complement system during immunotherapy of cancer with interleukin-2: a possible explanation of the capillary leak syndrome. Int J Biol Markers 5: 195-197, 1990.

9) Barnadas MA, Cistero A, Sitjas D, et al. Systemic capillary leak syndrome. J Am Acad Dermatol 32: 364-366, 1995.

10) Svensjo E, Persson CG, Rutili G. Inhibition of bradykinin induced macromolecular leakage from post-capillary venules by a beta2-adrenoreceptor stimulant, terbutaline. Acta Physiol Scand 101: 504-506, 1977.

11) Vassallo R, Lipsky JJ. Theophylline: recent advances in the understanding of its mode of action and uses in clinical practice. Mayo Clin Proc 73: 346-354, 1998.

12) Tahirkheli NK, Greipp PR. Treatment of the systemic capillary leak syndrome with terbutaline and theophylline. A case series. Ann Intern Med 130: 905-909, 1999.

13) Hiraoka E, Matsushima Y, Inomoto-Naribayashi Y, et al. Systemic capillary leak syndrome associated with multiple myeloma of IgG kappa type. Intern Med 34: 1220-1224, 1995.

14) Weinbren I. Spontaneous periodic oedema: A new syndrome. Lancet 18: 544-546, 1963.

15) Horwith M, Hagstrom JW, Riggins RC, et al. Hypovolemic shock and edema due to increased capillary permeability. JAMA 200: 101-104, 1967.

16) Larcan A, Calamai M, Heully MC, et al. Cyclic shock due to increased capillary permeability. Probable role of immunoglobulin G. Presse Med 77: 1931-1934, 1969.

17) Jacox RF, Waterhouse $C$, Tobin R. Periodic disease associated with muscle destruction. Am J Med 55: 105-110, 1973.

18) Larcan A, Laprevote MC, Lambert H. Cyclical shock with hyperglobulinemia. Bibl Anat 13: 343-346, 1975.

19) Atkinson JP, Waldmann TA, Stein SF, et al. Systemic capillary leak syndrome and monoclonal IgG gammopathy; studies in a sixth patient and a review of the literature. Medicine (Baltimore) 56: 225-239, 1977.

20) George C, Regnier B, Le Gall JR, et al. Hypovolemic shock with oedema due to increased capillary permeability. Intensive Care Med 4: 159-163, 1978.

21) Lofdahl CG, Solvell L, Laurell AB, et al. Systemic capillary leak syndrome with monoclonal $\mathrm{IgG}$ and complement alterations. A case report on an episodic syndrome. Acta Med Scand 206: 405-412, 1979.

22) Maestracci P, Benoit $P$, Dupeyrat J, et al. Hypovolemic shock due to increased capillary permeability (author's transl). Nouv Presse Med 10: 329 330, 1981.

23) Fossati C. Diuretics. I. Clin Ter 99: 313-316, 1981.

24) Janin-Manificat L, Martelet M, Guy H, et al. Hypovolemic shock caused 


\section{Capillary Leak Syndrome}

by increased capillary permeability. A case without monoclonal dysglobulinemie (letter). Nouv Presse Med 11: 2716, 1982.

25) de Barros RT, Chocair PR, Ianhez LE, et al. Systemic capillary leak syndrome. Report of a case and review of the literature. Rev Hosp Clin Fac Med Sao Paulo 38: 170-172, 1983.

26) Piette AM, De Rohan-Chabot P, Chapman A, et al. Hypovolemic shock caused by increased capillary permeability associated with monoclonal gammopathy. New case and review of the literature. Ann Med Interne 136: 572-574, 1985.

27) Cain JR, Bourgoignie JJ, Ahn YS, et al. Systemic capillary leak syndrome (SCLS): a rare cause of systemic edema. Kidney Int 29: 181, 1986 (Abstract).

28) Lagrue G, Rahbar K, Behar A, et al. Recurrent shock with monoclonal gammopathy. Treatment in the acute and chronic phases with oral and parenteral Ginkgo biloba extract. Presse Med 15: 1554-1555, 1986.

29) Garcia-Bragado F, Lima J, Monteagudo M, et al. Generalized capillary hyperpermeability syndrome: a rare cause of hypovolemic shock and cyclic generalized edemas. Contribution of 2 cases. Med Clin 89: 426-428, 1987.

30) Rondeau E, Sraer J, Bens M, et al. Production of 5-lipoxygenase pathway metabolites by peripheral leukocytes in capillary leak syndrome (Clarkson disease). Eur J Clin Invest 17: 53-57, 1987.

31) Fellows IW, Powell RJ, Toghill PJ, et al. Epoprostenol in systemic capillary leak syndrome. Lancet 2: 1143, 1988 (letter).

32) Ewan PW, Lachmann PJ, Morice AH, et al. Treatment of systemic capillary leak syndrome. Lancet 2: 1496, 1988.

33) Doorenbos CJ, van Es A, Valentijn RM, et al. Systemic capillary leak syndrome. Preventive treatment with terbutaline. Neth J Med 32: 178$184,1988$.

34) Daimaru O, Nitta M. Systemic capillary leak syndrome. Ryoikibetsu Shokogun Shirizu, Nipponrinshosha, 22 Pt 3: 578-581, 1998 (in Japanese).

35) Teelucksingh S, Padfield PL. Systemic capillary leak syndrome. Lancet 1: 330-331, 1989.

36) Navarro C, Garcia-Bragado F, Lima $\mathbf{J}$, et al. Muscle biopsy finding in systemic capillary leak syndrome. Hum Pathol 21: 297-301, 1990.

37) Droder RM, Kyle RA, Greipp PR. Control of systemic capillary leak syndrome with aminophylline and terbutaline. Am J Med 92: 523-526, 1992.

38) Kao NL, Richmond GW, Luskin AT. Systemic capillary leak syndrome. Chest 104: 1637-1638, 1993.

39) Kang PM, Lawrence C, Khan GA, et al. Fulminating systemic capillary leak syndrome with lymphocytosis and hypogammaglobulinemia. Ren Fail 17: 615-617, 1995.

40) Foeldvari I, Waida E, Junker AK. Systemic capillary leak syndrome in a child. J Pediatr 127: 739-741, 1995.

41) Brechignac $X$, Coppere B, Pinede L, et al. Capillary hyperpermeability syndrome: a new case. Rev Med Interne 16: 227-228, 1995 (in French).

42) Rauzy O, Adoue D, Arlet P. Chronic systemic capillary leak syndrome not requiring treatment? Am J Med 105: 360, 1998.

43) Stirling CM, Boulton-Jones JM, Simpson K. Progressive oedema in a 30year-old. Lancet 352: 450, 1998.

44) Airaghi L, Montori D, Santambrogio L, et al. Chronic systemic capillary leak syndrome. Report of a case and review of the literature. J Intern Med 247: 731-735, 2000. 